\title{
That Was the Week
}

$\mathrm{T}$

HERE ARE TOO MANY weeks for the calendar. Many of us have shared this feeling, I'm sure, and have been quietly derisive, if not derogatory of the cumbersome machinery necessary to get $\mathrm{Na}$ tional Library Week in orbit. The organizational structure is hardly appreciated or understood by many who think of this as another ALA activity. Even those intimately involved in this program sometimes fail to realize the purpose and dedication of those outside the library profession who give it so much time and effort.

The significance of a week devoted to the stimulation of interest in libraries and to the development and improvement of library service need not be in terms of what it means to the librarian. Rather, it may afford an opportunity for the librarian to inform his public of the significance and purpose of his business. It is true that we spend the entire year doing just this, and that many and divers means are used.

The public librarian often has a public relations expert trying to garner newspaper space. The school librarian tries to convince the teachers, principal, and students of the importance of the library and the need for time to use it. The academic librarian may appear isolated from pressure and politicism but

Dr. McNeal is President of ACRL and Director of Libraries in the University of Miami. is nonetheless engaged in presenting his needs to the administration and must seek all the help possible from faculty, students, and alumni to bring about new buildings, more book money, more financial support.

Why should we decry, and often ignore, an opportunity to further our ends through a device sponsored by an "outside" agency? This is in reality another opportunity to focus attention on the specific needs of our own situation at a time when national attention is being drawn to all libraries.

The National Book Committee initiated the program, with the endorsement of ALA. Much of the history appears in an editorial by Samray Smith in the ALA Bulletin of October 1957 at the inception of National Library Week. As members of the library profession, we all have a responsibility to participate in making effective the program sponsored on our behalf by many who are not librarians.

The needs of any library are continuing and not likely to be served by any one-week effort, no matter how concentrated it may be. We can, however, use the publicity accorded libraries in this particular week as a starting point for some new program, or as a basis for renewed emphasis on certain aspects of a continuing program. It is only practical to take advantage of the cumulative efforts at the national level by making every possible local application. 